
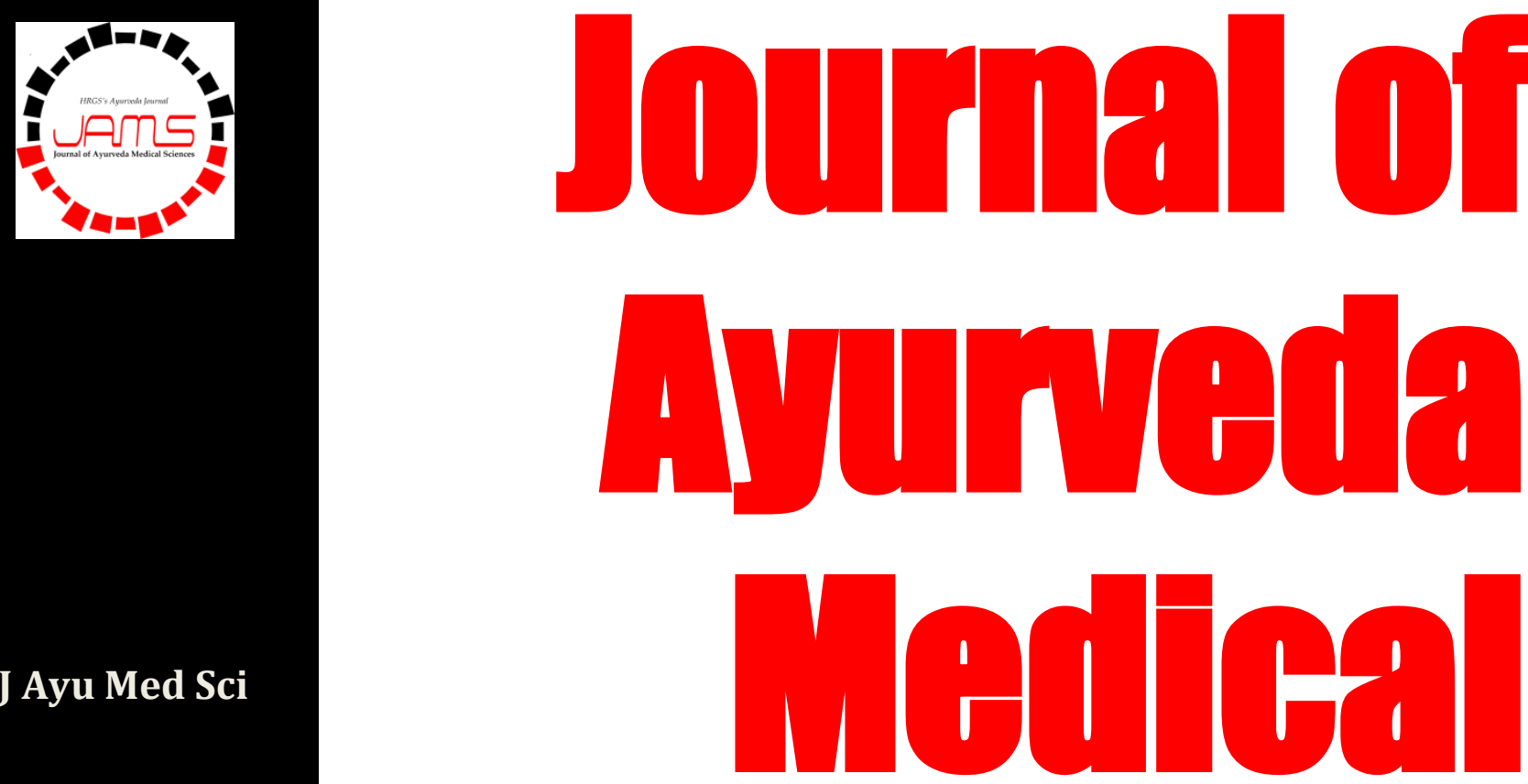

Quarterly Journal for

Rapid Publication

of Researches

in Ayurveda

and Other Traditional

Medicines

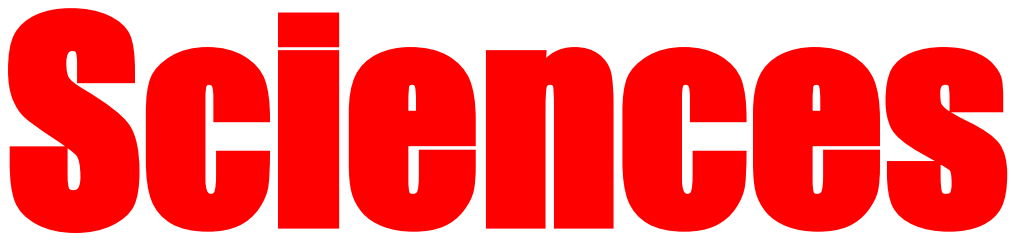

ISSN 2456-4990

\title{
Ghrita - Elixir: Child Growth and Development
}

Childhood is a crucial stage which a child undergoes physical and mental development. Adequate nutrition during this stage of life is very essential for appropriate growth and development of the child. According to Ayurveda, Grita (cow ghee) is one among the Nityasevaneeya dravya (the food article which can be taken on daily basis). Ghee is rich in fat soluble vitamins like vitamin $\mathrm{A}, \mathrm{E}$ and $\mathrm{K}$ which are very essential for growth and functioning of immune system. Cow ghee is full of essential nutrients, fatty acids, antibacterial, antifungal, antioxidants and antiviral properties, hence ghee plays major role in the development of milestone in children.

Negalur et al. 


\section{Ghrita - Elixir: Child Growth and Development}

Vijay B Negalur*, Krithi Amai

Department of PG Studies in Swasthavritta, Sri Dharmasthala Manjunatheshwara College of Ayurveda, Kuthpady, Udupi 574118 , India.

\section{ARTICLE HISTORY Received 01.11.2018 Accepted 30.03.2019}

CORRESPONDENCE Dr. Vijay B Negalur, Reader, Department of PG Studies in Swasthavritta, Sri Dharmasthala Manjunatheshwara College of Ayurveda, Kuthpady, Udupi 574118, India. Email: drvijaynegalur@gmail.com

CITE THIS CONCEPT NOTE AS Negalur VB, Amai K. Ghrita - Elixir: Child Growth and Development. J Ayu Med Sci 2018;3(3):402-4.

Today's children are tomorrow's citizen. Healthy society of the future relies on the health of the children today. Growth and development, the vital phenomena of childhood have a very important role in determining the health of the children and thereby the society. The term growth is described as the increase in the physical size of the body whereas development refers to increase in skills and functions. Thus, growth and development can be understood as improvement in physical, socio-emotional, cognitive and motor aspects. Factors such as genetic inheritance, nutrition, physical surroundings, psychological factors, economic factors etc influence the growth and development of a child.

Nutrition, one among the influencing factors has a very important role before as well as after birth. Adequate nutrition supply to a pregnant is very essential for optimum growth and development of the foetus. Maternal malnutrition is directly responsible for low birth weight of newborns, leading to higher risk of mortality and morbidity. Adequate nourishment of the child during infancy to age of puberty is equally important for their optimum growth and development. Ayurveda, the ancient healing science, describes in detail regarding care of the pregnant as well as child. Use of various dravya (drugs) for promoting the health of both mother and the child are available in the classics. One such dravya, being used since ages in India, in the form of food as well as medicine is ghrita (Ghee).

\section{Ghrita}

Ghrita, obtained by heating the navaneeta or butter, is one among the nityasevaniyadravya ${ }^{[1]}$ mentioned in the classics. Though ghrita can be obtained from various sources as milk of cow/ goat/ buffalo etc, ghee derived from cow's milk or 'gaughrita' is considered superior ${ }^{[2]}$.

\section{Properties}

Ghrita is said to have madhura rasa (sweet in taste), shitavirya (cold potency or cooling effect), helps in improving smriti (memory), medha (intellect), improves oja and bala (immunity and physical strength), and is kaphavardhaka ${ }^{[3]}$. It also helps in improving the health of the eyes, luster of the skin and clarity of voice. In addition, ghrita has the property of samskara anuvartana ${ }^{[4]}$ i.e., ghrita attains the qualities of the drug processed with it and does not lose its original properties.

\section{Ghee - Nutritive Value}

Ghee is composed of $60-65 \%$ of saturated fats, $27 \%$ of mono unsaturated fatty acids (MUFA) and $2-3 \%$ of poly unsaturated fatty acids (PUFA). It also has linoleic acid - an omega 6 fatty acid and $\alpha$ - linoleic acid - an omega 3 fatty acid. Ghee also contains fat soluble vitamins like vitamin A, D, E and K, Docosahexaenoic acid (DHA) and conjugated linoleic acid $(\mathrm{CLA})^{[5]}$

\section{Ghrita in various stages of life}

The role of intake of ghrita in various stages of life is described in the classical texts of Ayurveda. Various formulations of ghrita described in different stages of life of a child, may be discussed in the headings as - before (pre - natal period) and after birth.

\subsection{Ghrita: Pre - natal period}

The classic of Ayurveda describes various measures to be followed for attainment of healthy progeny. Various measures are described right from pre conception period, throughout the pregnancy for attainment of healthy baby. Ghrita is one such dravya which is given importance at these stages. Ghrita processed with drugs such as aindri, brahmi, patala, guduchi etc is advised for the purpose of garbhasthapana ${ }^{[6]}$. 
Describing the diet of garbhini, Acharya Sushruta describes that a pregnant woman should always consume food having properties such as madhura, shita and drava. Such food articles should be taken along with kshirasarpi in fifth month, shvadamshtra siddha sarpi in the sixth month, and prithakparnyadi siddha sarpi in seventh month. In the eighth month of gestation, drugs such as bala, atibalaetc along with ghrita is advised for asthapanabasti ${ }^{[7]}$. Thus, from pre conception throughout pregnancy, ghrita is being used for nourishment and care of the pregnant woman, ensuring the birth of healthy progeny.

\subsection{Ghrita: Infancy and Childhood}

Soon after the birth of a baby, after following jata karma such as cutting umbilical cord and giving bath, a lehya prepared out of medhyadravya such as aindri, brahmi, vacha and shankhapushpa along with ghrita and madhu is administered to the baby. As breast milk production starts from $3^{\text {rd }}$ or $4^{\text {th }}$ day of delivery,administration of Ananta mishramadhu- sarpi three times on first day of the birth is advised by Acharya Vagbhata to meet the nutritional needs of the baby. On the second and third day, Lakshmana siddha sarpi is indicated three times a day ${ }^{[8]}$.

Few other ghrita formulations are described for promoting intellectual and cognitive development of the child, such as Brahmi siddhartakadi siddha ghrita, Vachadi siddha ghrita, Saraswataghrita, etc ${ }^{[9]}$. Many more such formulations are described in the classics. Furthermore, medicines in the form of lehya are also advised for intellectual and cognitive development of children. In this context, suvarna (gold) along with other drugs are to be mixed with ghrita and madhu to obtain lehya consistency and is to be administered to the child ${ }^{[10]}$.

Acharya Sushruta enlisted Ghrita as one among the jatisatmyadravya. It is also considered one among the nityasevaniyadravya. Thus, it is evident that ghrita can be regularly consumed and administered to any age group. Owing to its property of samskara anuvartana, it is the most suitable snehadravya which can carry all possible medicinal properties of the desired drug to desired site of the body.

\section{Probable mode of action}

Ghrita being madhura, shita, snigdha and kaphavardhaka, is directly related with physical growth of the children. Kapha is an essential factor for growth and development in childhood. Madhura rasa, snigdhaguna and shitavirya of ghrita help in enhancing kapha and thus help in optimum growth and development. It is also said to be medhya and smritikara, i.e., aids in intellectual development whileojokara and balakara properties enhance the immunity of the child.

Ghrita having the property of samskarasyaanuvartana, could be the main reason for selecting it in different formulations. When medhya and balyadravyas are processed with ghrita, ghrita attains all the medicinal properties. When such ghrita is consumed, it carries the medicinal properties effectively to the desired sites, thus promotes growth and development in children.Ghrita is also recognized as one among ekantahitadravya as it is jatisatmya ${ }^{[11]}$. Enlisting the dravyas ideal for regular consumption, Acharya Charaka has mentioned ghrita as one among the nityasevaniyadravya. These properties uphold the selection of ghrita as a vehicle for administration of desired drug in promoting growth and development.

Blood brain barrier is a semipermeable membrane which hinders the delivery of therapeutic agents to the brain. It allows very few substances such as lipid soluble molecules, glucose and specific proteins to pass through it ${ }^{[12]}$. Drugs administered for mental development of the child has to cross this barrier to get the desired effect. Ghee is one such formulation, which when processed with medicinal drugs can absorb the lipid soluble active principles from the drug. Being lipid in nature, ghee may be able to cross the lipid soluble therapeutic agents across the blood brain barrier and dispense them to the target site, thus endorsing the mental development.

Ghee is also rich in fat soluble vitamins like vitamin A, E and $\mathrm{K}$ which are very essential for growth and functioning of immune system. Ghee also comprises of omega 3 fatty acids, Docosahexaenoic acid (DHA) and conjugated linoleic acid (CLA) which are beneficial in cognitive development.

Childhood is a crucial stage which a child undergoes physical and mental development. Adequate nutrition during this stage of life is very essential for appropriate growth and development of the child. Ghrita, being madhura, sowmya, balya and medhya can be administered as it is or by processing with other essential dravyas, to ensure optimum growth and development in children. Thus, owing to its properties, ghrita acts as an elixir in growth and development of children.

ACKNOWLEDGMENT Author highly grateful to principal SDM College of ayurveda kuthpady udupi Karnataka for continues encouragement and support.

\section{SOURCE OF SUPPORT Nil}


CONFLICT OF INTEREST The authors declare no conflict of interest.

CONTRIBUTORS Dr Vijay contributed to the conceptualization of the topic and Dr Kruti contributed to study design and literature survey.

\section{REFERENCES}

1. Vaidya YadavjiTrikamji Acharya, editor (reprinted ed.). Charaka Samhita of Agnivesha, SootraSthana; Maatraashitiyamadhyaayam: Chapter 5, Verse 12 - 13. Varanasi: Chaukambha Orientalia, 2011; p.38.

2. Vaidya YadavjiTrikamji Acharya, editor (reprinted ed.). Sushruta Samhita of Sushruta, SootraSthana; Dravadravyavidhimadhyaayam: Chapter 45, Verse 97. Varanasi: ChaukhambaSurbharatiPrakashan, 2003; p.204.

3. Vaidya YadavjiTrikamji Acharya, editor (reprinted ed.). Charaka Samhita of Agnivesha, SootraSthana; Annapaanavidhimadhyaayam Chapter 27, Verse 231. Varanasi: Chaukambha Orientalia, 2011; p.166.

4. Vaidya YadavjiTrikamji Acharya, editor (reprinted ed.). Charaka Samhita of Agnivesha, NidaanaSthana; Jvaranidaanam: Chapter 1, Verse 40. Varanasi: Chaukambha Orientalia, 2011; p.203.

5. Yogita Surendra Karandikar, Akshata Sanjay Bansude, EeshaAjitAngadi. Comparison between the effect of cow ghee and butter on memory and lipid profile of wistar rats. J Clin Diagn Res 2016;10(9):11-5.

6. Vaidya YadavjiTrikamji Acharya, editor (reprinted ed.). Charaka Samhita of Agnivesha, ShaareeraSthana; JaatisutreeyamShaareeram Chapter 8, Verse 20. Varanasi: Chaukambha Orientalia, 2011; p.343.

7. Vaidya YadavjiTrikamji Acharya, editor (reprinted ed.). Sushruta Samhita of Sushruta, ShaareeraSthana; GarbhineevyaakaranaShaareeram: Chapter 10, Verse 4. Varanasi: ChaukhambaSurbharatiPrakashan, 2003; p.387.

8. Pt. Hari SadashivaSastriParadakara, editor ( $\left(1^{\text {st }}\right.$ ed.). Ashtangahdaya of Vagbhata, Uttarasthana; Baalopacharaneeyamadhyaayam: Chapter 1, Verse 12 - 13. Varanasi: ChaukhambaSurbharatiPrakashan, 2016; p.778.

9. Pt. Hari SadashivaSastriParadakara, editor ( $1^{\text {st }}$ d. $)$. Ashtangahdaya of Vagbhata, Uttarasthana; Baalopacharaneeyamadhyaayam: Chapter 1, Verse 42 - 44. Varanasi: ChaukhambaSurbharatiPrakashan, 2016; p.780.

10. Pt. Hari SadashivaSastriParadakara, editor ( $1^{\text {st }}$ d.). Ashtangahdaya of Vagbhata, Uttarasthana; Baalopacharaneeyamadhyaayam: Chapter 1, Verse 47 - 48. Varanasi: ChaukhambaSurbharatiPrakashan, 2016; p.781.

11. Vaidya YadavjiTrikamji Acharya, editor (reprinted ed.). Sushruta Samhita of Sushruta, SootraSthana; Hitaahiteeyamadhyaayam: Chapter 20, Verse 4. Varanasi: ChaukhambaSurbharatiPrakashan, 2003; p.94.

12. Sl Rapoport, Kt Ohno, KD Pettigrew. Drug entry into the brain. Brain Research 1979;172(2):354-9. 